\title{
ДО ПРОБЛЕМИ ЛЕКСИКОГРАФІЧНОГО ОПИСУ СТАЛИХ СПОЛУЧЕНЬ РОСІЙСЬКОЇ, УКРАЇНСЬКОЇ І ПОЛЬСЬКОЇ МОВ
}

Аналіз наявних лексикографічних джерел російської, української і польської мов дав змогу висновкувати, що система подання в них сталих сполучень слів виявляється мало зручною для користувачів цих пращь. Особливі ускладнення виникають у процесі перекладацької діяльності. Доводиться, що назріла нагальна необхідність у створенні комплексних словників сталих сполучень усіх типів для кожної мови окремо, які в подальшому слугуватимуть джерельною базою для перекладу їхніх структурних компонентів іншими мовами. Метою пропонованої роботи є визначення шляхів формування концепції нового типу комплексного словника з реєстровими нарізнообормленими одинииями.

Ключові слова: тексикограбія, словник, сталі сполучення слів, реєстр, реєстрова одиниия, словникова стаття.

\section{Luchyk A. On the Problem of Lexicographic Description of Stable Word} Combinations in Russian, Ukrainian and Polish Languages. The analysis of the available lexicographic sources of the Russian, Ukrainian and Polish languages led to the conclusion that the system of presenting stable word combinations in basic dictionaries is not very convenient for the users of these works. Particular difficulties arise during translation. Meanwhile, in Russian, Ukrainian and Polish linguistics there are numerous publications with registers formed by permanent links. Each of these dictionaries is designed to normalize a certain differently designed class of units, has its own structure and organization principles. Thus, there is an urgent need to create comprehensive dictionaries of stable word combinations of all types for each language separately, which will later serve as the initial basis for translating their structural components into other languages. The aim of the proposed work is to determine the ways of forming a new type complex dictionary concept with registered differently-formed units.

First of all, lexicographic works with registered differently-formed units, which comprise word equivalents, including adverbs, prepositions, conjunctions, exclamations, particle equivalents, etc., as well as terminological combinations, phraseological units, etc., can be arranged separately for each language. In the future, they will serve as the initial basis for translation dictionaries.

The article proposes certain principles of organizing a new type of lexicographic works, which should reflect both the general properties of stable combinations with different properties of their functioning, and the features of differentiation. 
The presented fragmentary concept of the specified lexicographic work creation can only be an impetus for its comprehensive formation and discussion for the purpose of taking into account a wide range of offers from experts. The ultimate goal of the proposed research may be a stable publication of complex dictionaries of Russian, Ukrainian and Polish languages.

Key words: lexicography, dictionary, stable word combinations, register, registered unit, dictionary entry.

\section{Вступ}

Сьогодні лексикографічна діяльність російських учених переживає справжній бурхливий розквіт. Регулярно поповнюється склад фундаментальних словників російської мови. Це й тлумачні, й універсальні, і фразеологічні, й орфографічні, орфоепічні словники, і словники синонімів, антонімів, семантичні словники тощо. Значну увагу тут приділяють і периферійним одиницям мовної системи, що підтверджується наявністю словників жаргонної лексики, сленгу, абревіатур іншомовного походження, модних слів, словників мови інтернету тощо. І це зрозуміло, оскільки «сучасна наука прагне втілити у словниковій формі всі аспекти отриманих знань; словники не лише фіксують сукупність певних знань, але й є надійним інструментом наукового освоєння дійсності» (Широков, 2018: 7).

На жаль, дещо призупинена робота над перекладними дво-, багатомовними, крім російсько-англійських та англо-російських, словників, а також доопрацювань того лексикографічного надбання, що було закладене в минулому столітті, як, наприклад, «Большой академический монгольско-русский словарь» (Пюрбеев, 2001-2002). Сьогодні російсько-слов'янські й слов'яно-російські словники переважно упорядковують поза межами російської мовознавчої школи, у зв'язку із чим виникають певні труднощі.

У процесі укладання перекладних дво- чи багатомовних словників слов'янських мов постає питання реєстру словника. Тут передовсім варто враховувати той факт, що мова - динамічна система, у якій одиниці, зокрема й слова та сталі сполучення, перебувають у постійному русі, а сьогоднішні їні характеристики часто не збігаються з тими, що фіксувалися в базових словниках, виданих кілька років тому. Ще одним важливим питанням $€$ комплексне лексикографування ідіоматичного складу одиниць. Власне, на останньому й зосередимося в пропонованій праці. 


\section{Методи дослідження}

Для висвітлення поставленої проблеми в статті використано такі загальнонаукові методи, як спостереження, індукція, дедукція. На основі описового методу узагальнено лексикографічне надбання російської, української й польської мовознавчих шкіл щодо репрезентації сталих сполучень у структурі словникової статті. Зіставний метод дослідження дав змогу виявити спільні й відмінні риси в способах репрезентації нарізнооформлених одиниць із цілісною семантикою російськими, українськими й польськими лексикографами. У процесі визначення термінологічних назв у мовах опису словників використано прийоми, що грунтуються на відбитті диференційних ознак наукової систематики (див. Киселевский, 1977).

\section{Виклад основного матеріалу}

Нарізнооформлені одиниці, яким властива цілісність семантики, усе частіше формують реєстровий склад одно- або двомовних спеціалізованих словників (Лучик 2003; Лучик, 2006; Космеда, 2017; Тимошук, 2018), часом вони входять до реєстру лексикографічної праці на рівних правах із традиційними представниками словникової статті (Морковкин, 2003). Проте, на жаль, у базових, зокрема й перекладних словниках будь-якої слов'янської мови нарізнооформлені структури, за деякими винятками, містяться в так званій заромбовій частині словникової статті з реєстровим словом, що входить до складу фразеологізованої одиниці як основний їі смисловий центр. У сучасній українській лексикографії представлення цих сталих сполучень ще більш подрібнене. Іншим шляхом ідуть автори нового «Словника української мови» у 20-ти томах. У передмові до нового словника стосовно нарізнооформлених одиниць, які називаються словосполученнями, зазначено, що упорядники виділяють зону усталених словосполучень, їх наводять після характеристик лексичних значень слова. Перша група - стійкі словосполучення, тобто усталені у своєму лексичному поєднанні звороти, що складаються в основному зі слів у їхніх власних значеннях і відтворюються в процесі спілкування як неподільні мовні одиниці, у яких можлива незначна десемантизація одного з компонентів. Прикладами таких словосполучень уважають такі: груба їжа проста, важка для травлення їжа; за алфавітом - за алфавітним порядком літер, прийнятим у мові тощо. 
Друга група - еквіваленти слова - своєрідні перифрастичні словосполучення, рівнозначні слову, які $є$ цілісними усталеними відтвореними одиницями, що прирівнюються до лексико-граматичних класів слів (частин мови) із властивими для них лексичними значеннями без десемантизації компонентів (завдяки тому, що; з того иасу, як тощо).

Третю групу формують термінологічні словосполучення, які стосуються різних галузей знань і $є$ елементами відповідних галузевих терміносистем (анабілактичний шок, ератичні валуни тощо).

До четвертої групи словосполучень належать фразеологічні одиниці - усталені за складом і структурою лексично неподільні словосполучення, що виражають цілісне специфічне фразеологічне значення, яке не є сумою значень його компонентів, а виникає на основі ї переосмислення переважно завдяки метафоричним і метонімічним процесам (високо нестися, підводне каміння тощо) (Русанівський, 2010: 24-25).

Таке розміщення матеріалу, на нашу думку, не скорочує шляхи пошуку тієї чи тієї одиниці в словнику. До того ж у цьому разі підвищуються вимоги до пінгвістичної підготовки користувача. Крім необхідної бази знань про встановлення головного слова в словосполученні, користувач повинен уже мати уявлення про типи словосполучень: усталені словосполучення, еквіваленти слова, термінологічні словосполучення чи власне фразеологізми. На жаль, можна констатувати, що такою обізнаністю володіє навіть не кожен мовознавець.

3 погляду теорії мовознавства пропонований підхід $€$ цілком виправданим. Проте, виходячи з потреб користувача, зазначене упорядкування матеріалу є досить незручним. Причин тут кілька. По-перше, словникова стаття в цьому разі може бути досить об'ємною, і для того, щоб віднайти те чи те стале сполучення, потрібно чимало часу. Наприклад, до реєстрової одиниці нога за знаком $\oslash$ у «Словаре русского языка» подається понад 60 стійких словосполучень (Евгеньева, 1987: 737-738), а з лексемою рука - понад 130 одиниць (Евгеньева, 1986: 506). Відповідно, у «Словнику сучасної української мови» за лексемою нога міститься понад 100 сталих сполучень (Білодід, 1974: 437439 ), у словниковій статті з реєстровим словом рука - понад 250 (Білодід, 1977: 899-905). Подібні явища можна спостерігати й у польських джерелах, де за словом noga може бути зафіксовано понад 100 
сталих сполучень (Dubisz, 2008: 948-951) і понад 200 фразеологізованих одиниць після реєстрової одиниці ręka (Dubisz, 2008: 1011-1013). Розміщення останніх у зазначених лексикографічних джерелах відбувається, з одного боку, не за алфавітом, а з другого, - значна їх кількість супроводжується посиланнями на інші словникові статті. Крім того, часто в дужках подаються варіантні утворення, факультативні елементи. Наприклад, у «Словаре русского языка», де з реєстровою одиницею глаз пов'язується близько 100 фразеологізованих сполучень, знаходимо такі посилання в групі останніх: Вороний глаз см. вороний; протереть глаза см. протереть; тигровый глаз см. тигровый тощо (Евгеньева, 1985: 313-314). Для швидшого пошуку необхідної одиниці користувачеві словника в цьому разі доводиться з'ясовувати, яке слово в складі фразеологічної одиниці лексикограф вважає головним, оскільки в передмові до «Словаря русского языка» зазначено, що пояснення стійкого сполучення запропоновано під тим словом, яке в цьому вислові $є$ найбільш значущим (Евгеньева, 1985: 9). Ускладнює процес пошуку й той факт, що в разі наявності синонімів до одного зі слів стійкого сполучення в дужках подається синонім так, як це відбувається і з факультативним елементом, наприклад: Проглядеть (или просмотреть) (все) глаза; Смотреть (или глядеть) другими (или иными) глазами (Евгеньева, 1985: 313).

Подібну традицію упорядкування стійких сполучень спостерігаємо й у базових словниках інших слов'янських мов. Зокрема, у «Словнику української мови» за реєстровою одиницею око подано понад 200 стійких сполучень, де ситуація ускладнюється ще й поданням граматичних та орфоепічних варіантів. Пор.: Бісики (бісик) в очах (в оці) [грають (грає і т. ін.)]; Дивитися (зазирати, заглядати, глянути й т. ін.) смерті (небезпеці) в очі (у вічі); Зміряти (змірювати, зміряти, змірити) очима (оком) див. зміряти (Білодід, 1974: 665-667).

Зрозуміло, що за необхідності пізнання властивостей тієї чи тієі сполуки, до того ж для її перекладу цільовою мовою, такий спосіб розміщення матеріалу значно утруднює пошукову діяльність користувача. У перекладних же загальномовних словниках нарізнооформлені одиниці здебільшого не потрапляють до реєстру. Зазвичай для сталих сполучень різного типу укладають спеціалізовані словники: фразеологічні, еквівалентів слова, словники ідіом, порівняльних слів, крилатих висловів тощо. Часом як реєстрові одиниці стійкі сполучення 
фіксуються в словниках службових, вигукових або структурних слів. У будь-якому разі для користувача пошук сталого сполучення в лексикографічних працях для розуміння його семантичних, стилістичних тощо властивостей викликає неабиякі труднощі. Особливі проблеми стосовно нарізнооформлених одиниць виникають у перекладацькій діяльності, коли за необхідності перекласти ту чи ту усталену сполуку потрібно здійснити кілька входів до лексикографічної праці, і це не обов'язково сприятиме позитивному результату. 3 висловленого випливає, що назріла нагальна необхідність у створенні нового типу комплексного словника сталих сполучень, реєстр якого 6 формувався еквівалентами слова, термінологічними сполученнями, власне фразеологізмами й под., на чому ми наголошували в попередніх публікаціях (Luchyk, 2015).

Ідея такої лексикографічної праці не $є$ новою. Ще в середині минулого століття Х. Касарес, обстеживши властивості сукупностей двох або більше слів, що мають незмінний порядок компонентів, семантичну єдність та характеризуються невизначеністю своєї належності до певних стратумів мови, дійшов висновку: «Щоб спробувати зробити дослідження, необхідно було б написати цілу граматику висловів»( Касарес, 1958: 197).

Відомо, що й досі принаймні жодною слов'янською мовознавчою школою такої граматики не створено, проте в лексикографічній практиці з'явилися всі передумови для укладання комплексного словника сталих словосполучень більшості слов'янських мов. Для упорядкування такого словника російської мови джерельною базою можуть слугувати, крім фундаментальних тлумачних словників з розгорненою позаромбовою частиною, численні фразеологічні, термінологічні словники, словники еквівалентів слова, структурних слів тощо, а в подальшому, можливо, і словники порівняльних зворотів, прислів'їв і приказок. Така база є, наприклад, і в українському та польському лексикографічному надбанні. Це, крім сучасних багатотомних тлумачних словників, словники службових слів, до складу яких зараховано максимальну кількість нарізнооформлених одиниць, словники еквівалентів слова, фразеологічні й словники прислів'їв і приказок, словники порівнянь і под. Значна кількість цих праць має перекладний характер, що, з одного боку, засвідчує нагальну потребу подібних робіт для перекладацької діяльності, а з другого, - висвітлює 
шляхи можливого структурування як базового одномовного словника сталих сполучень, так й упорядкованих на його основі перекладних словників.

У процесі укладання словника сталих сполучень необхідним буде врахування і притаманних рівною мірою всім зазначеним структурам ознак форми вираження, внутрішньої організації, особливостей функціонування. Беззаперечно, об’єднувальними критеріями стануть такі їні характеристики, як нарізнооформленість, цілісність значення, відтворюваність, проте одночасно в кожному типі сполучень наявні специфічні характеристики, які теж мають знайти відбиття в майбутньому словнику.

Під час підготовки словника нового типу особливу увагу варто приділити його композиційній структурі. Очевидно, реєстрові одиниці будуть розташовані за алфавітом, а сам словник складатиметься, як і базові тлумачні лексикографічні праці, з лівої і правої частин. Зрозуміло, що, коли йдеться про перекладні різновиди таких лексиконів, структура останніх буде дещо складнішою. Права частина передбачає виклад змісту лексичного значення, тобто до кожної реєстрової одиниці додаватиметься семантична характеристика у формі тлумачення, яка буде необхідною й у перекладних словниках. Така практика вже відома й застосовується в працях подібного типу (Рогожникова, 1991; Лучик, 2003, 2006; Космеда, 2017; Тимошук, 2018).

\section{Висновки}

У пропонованій роботі доведено, що в межах російської, української й польської лінгвістичних шкіл сформувалися всі умови для укладання словників нового типу, реєстровий склад яких формувався 6 з усіх видів сталих сполучень слів. Першочергово такі лексикографічні праці можуть бути впорядковані окремо для кожної мови. У подальшому вони слугуватимуть джерельними базами для перекладних словників. Подана фрагментарна концепція створення зазначеної лексикографічної праці може бути лише поштовхом для їі всебічного формування й обговорення $з$ урахуванням пропозицій широкого кола фахівців.

\section{ЛІТЕРАТУРА}

1. Білодід, І. К. (Ред.) (1974). Словник украӥнської мови. (Т. 5). Київ: Наук. думка. 2. Білодід, І. К. (Ред.) (1977). Словник украӥнської мови. (Т. 7). Київ: Наук. думка. 3. Евгеньева, А. П. (Ред.) (1985). Словарь русского языка. (Т. 1). Москва: Русский язык. 
4. Евгеньева, А. П. (Ред.) (1986). Словарь русского языка. (Т. 2). Москва: Русский язык. 5. Евтеньева, А. П. (Ред.) (1987). Словарь русского языка. (Т. 3). Москва: Русский язык. 6. Касарес, X. (1958). Введение в современную лексикографию. Москва: Изд-во иностр. лит. 7. Киселевский, А. И. (1977). Языки и метаязыки энциклопедий и толковых словарей. Минск: Изд-во Белорус. ун-та. 8. Космеда, Т., Гоменюк, О., \& Осіпова, Т. (2017). Короткий українсько-польський словник усталених виразів: еквіваленти слова, фразеологізми, прислів'я і приказки. Познань-Харків: Вид-во «Коло». 9. Лучик, А. (2006). Словник еквівалентів слова української мови. Katowice : Wyd-wo US. 10. Лучик, А. (2003). Російсько-украӥнський та украӥнсько-російський словник еквівалентів слова. Київ: Довіра. 11. Морковкин, В. В. (Ред.) (2002). Объяснительный словарь русского языка: структурные слова: предлоги, союзы, частицы, междометия, вводные слова, местоимения, числительные, связочные глаголы. Москва: Астрель: АСТ. 12. Пюрбеев, Г. Ц. (Ред.) (2001-2002). Большой академический монгольско-русский словарь. (Т. 1-4). Москва: Akademia. 13. Рогожникова, Р. П. (1991). Словарь эквивалентов слова: наречные, служебные, модальные единства. Москва: Русский язык. 14. Русанівський, В. М. (Ред.) (2010). Словник української мови. (Т. 1). Київ: Наук. думка. 15. Тимошук, Р., Сосновський, В., Яскот, М., \& Ганошенко, Ю. (2018). Лексикон польської та української активної фразеологіi. Варшава: KJV Digital. 16. Широков, В. А. (Ред.) (2018). Лінгвістично-інформаиійні студії: Праиі Українського мовно-інформаційного фонду НАН України. (Т. 3., Кн. 1). Київ: Укр. мовно-інф. фонд НАН України. 17. Dubisz, S. (Ред.) (2008). Uniwersalny stownik języka polskiego PWN. (Т. 2). Warszawa: Wyd-wo naukowe PWN. 18. Dubisz, S. (Ред.) (2008). Uniwersalny stownik języka polskiego PWN. (T. 3). Warszawa: Wyd-wo naukowe PWN. 19. Luchyk, A. (2013). Interpretation of Ukrainian and Polish Adverbial Word Equivalents Form and Meaning Interaction in National Explanatory Lexicography. Cognitive studies/ Etudes cognitives/ Warsaw: University of Silesia in Katowice/ The Slavic Foundation, 13, 35-42. DOI 10.11649/cs.2013.018.

\section{REFERENCES}

1. Bilodid, I. K. (Red.) (1974). Slovnyk ukrainskoi movy [Dictionary of the Ukrainian language]. (Vol. 5). Kyiv: Nauk. dumka [in Ukrainian]. 2. Bilodid, I. K. (Red.) (1977). Slovnyk ukrainskoi movy [Dictionary of the Ukrainian language]. (Vol. 7). Kyiv: Nauk. dumka [in Ukrainian]. 3. Evgen'eva, A. P. (Red.) (1985). Slovar' russkogo jazyka. (Vol. 1). Moskva: Russkij jazyk [in Russian]. 4. Evgen'eva, A. P. (Red.) (1986). Slovar' russkogo jazyka [Dictionary of the Russian language]. (Vol. 2). Moskva: Russkij jazyk [in Russian]. 5. Evgen'eva, A. P. (Red.) (1987). Slovar' russkogo jazyka [Dictionary of the Russian language]. (Vol. 3). Moskva: Russkij jazyk [in Russian]. 6. Kasares, K. H. (1958). Vvedenie v sovremennuyu leksikografiyu [Introduction to modern lexicography]. Moskva: Izd-vo inostr. lit. [in Russian]. 7. Kiselevskij, A. I. (1977). Yazyki i metayazyki ehntsiklopedij i tolkovykh slovarej [Languages and metalanguages of encyclopedias and dictionaries]. Minsk: Izd-vo Belorus. un-ta [in Belarus]. 8. Kosmeda, T., Homeniuk, O., \& Osipova, T. (2017). Korotkyi ukrainsko-polskyi slovnyk ustalenykh vyraziv: ekvivalenty slova, frazeolohizmy, pryslivia i prykazky [Short Ukrainian-Polish dictionary of established expressions: word equivalents, phraseologies, proverbs and sayings]. Poznan-Kharkiv: Vydavnytstvo «Kolo» [in Ukrainian]. 9. Luchyk, A. (2006). Slovnyk ekvivalentiv slova ukrainskoi movy [Dictionary of word equivalents of the Ukrainian language]. Katowice: Wyd-wo US. 10. Luchyk, A. (2003). Rosiisko-ukrainskyi ta 
ukrainsko-rosiiskyi slovnyk ekvivalentiv slova [Russian-Ukrainian and Ukrainian-Russian Dictionary of Equivalent Words]. Kyiv: Dovira [in Ukrainian]. 11. Morkovkin, V. V. (Red.) (2002). Ob»yasnitel'nyj slovar' russkogo yazyka: strukturnye slova: predlogi, soyuzy, chastitsy, mezhdometiya, vvodnye slova, mestoimeniya, chislitelnye, svyazochnye glagoly [Explanatory dictionary of the Russian language: structural words: prepositions, conjunctions, particles, interjections, introductory words, pronouns, numbers, connective verbs]. Moskva: Astrel': AST [in Russian]. 12. Pyurbeev, G. TS. (Red.) (2001-2002). Bol'shoj akademicheskij mongol'skorusskij slovar' [Comprehensive academic Mongolian-Russian dictionary]. (T. 1-4). Moskva: Akademia [in Russian]. 13. Rogozhnikova, R. P. (1991). Slovar' ehkvivalentov slova: narechnye, sluzhebnye, modal'nye edinstva [Dictionary of word equivalents: adverbial, service, modal unity]. Moskva: Russkij yazyk [in Russian]. 14. Rusanivskyi, V. M. (Red.) (2010). Slovnyk ukrainskoi movy [Dictionary of the Ukrainian language]. (T. 1). Kyiv: Naukova dumka [in Ukrainian]. 15. Tymoshuk, R., Sosnovskyi, V., Yaskot, M., \& Hanoshenko, Yu. (2018). Leksykon polskoi ta ukrainskoi aktyvnoi frazeolohii [Lexicon of Polish and Ukrainian active phraseology]. Varshava: KJV Digital [in Poland]. 16. Shyrokov, V. A. (Red.) (2018) Linhvistychno-informatsiini studii: Pratsi Ukrainskoho movno-informatsiinoho fondu NAN Ukrainy [Linguistic and information studies: Proceedings of the Ukrainian Language and Information Fund of the National Academy of Sciences of Ukraine]. (T. 3., Kn. 1). Kyiv: Ukr. movno-inf. fond NAN Ukrainy [in Ukrainian]. 17. Dubisz, S. (Ред.) (2008). Uniwersalny słownik języka polskiego PWN [Uniwersalny słownik języka polskiego PWN]. (T. 2). Warszawa: Wyd-wo naukowe PWN [in Polish]. 18. Dubisz, S. (Ред.) (2008). Uniwersalny słownik języka polskiego PWN [Uniwersalny słownik języka polskiego PWN]. (T. 3). Warszawa: Wydwo naukowe PWN [in Polish]. 19. Luchyk, A. (2013). Interpretation of Ukrainian and Polish Adverbial Word Equivalents Form and Meaning Interaction in National Explanatory Lexicography. Cognitive studies/ Etudes cognitives/ Warsaw: University of Silesia in Katowice/ The Slavic Foundation, 13, 35-42. DOI 10.11649/cs.2013.018 [in Polish].

Лучик Алла Анатоліївна - доктор філологічних наук, професор, професор кафедри загального і слов'янського мовознавства, Національний університет «КиєвоМогилянська академія»; вул. Г. Сковороди, 2, м. Київ, 04070, Україна.

Tel.: +38-050-341-00-93

E-mail: allal@meta.ua

https://orcid.org/0000-0002-4218-355X

Luchyk Alla Anatoliivna - Doctor of Philological Sciences, Professor, Professor at the Department of General and Slavic Linguistics, National University of «Kyiv-Mohyla Academy»; G. Skovorody Str., 2, Kyiv, 04070, Ukraine.

Надійшла до редакції 25 вересня 2020 року

\section{CITATION}

ДСТУ 8302:2015: Лучик А. А. До проблеми лексикографічного опису сталих сполучень російської, української і польської мов. Лінгвістичні дослідження: зб. наук. пр. Харк. нац. пед. ун-ту імені Г. С. Сковороди. Харків, 2020. Вип. 53. С. 200-208. DOI: https://doi.org/10.34142/23127546.2020.53.18

APA: Лучик, А. А. (2020). До проблеми лексикографічного опису сталих сполучень російської, української і польської мов. Лінгвістичні дослідження, 53, 200-208. DOI: https://doi.org/10.34142/23127546.2020.53.18 